Journal of Islamic Education Policy

2017, Vol.2, No.1, $34 \quad 44$

Diterbitkan Online Desember 2017 (http://journal.iain-manado.ac.id/index.php/jiep)

\title{
Pengaruh Pemahaman Agama terhadap Kinerja Guru Madrasah Ibtidaiah di Kota Manado
}

\section{Rivai Bolotio}

Fakultas Tarbiyah dan Ilmu Keguruan, Institut Agama Islam Negeri (IAIN) Manado, Sulawesi Utara Email: rivaibolotio@iain-manado.ac.id

\begin{abstract}
This study aims to examine the influence of religious understanding on the performance of Madrasah Ibtidaiah teachers in Manado City. The method used in this research is correlational quantitative. This research is conducted in Madrasah Ibtidaiah in Manado City with the sample size of 96, selected from 127 teachers using proportional stratified random sampling. Data collection is done by using test and nontest instruments. The test is used to collect data on religious understanding and the nontest is used to collect the data of practice and performance. The collected data are then analyzed using descriptive analysis and path analysis. The results of this study indicate that religious understanding has a positive direct effect on teacher performance. To improve teachers' performance, the efforts made, in relation to these variables, include improving teachers ' religious understanding by renewing teachers' religious knowledge by strengthening faith and devotion to God, and increasing selfawareness that obedience and sincerity in applying it are inevitable.
\end{abstract}

Keywords: Religious understanding, performance, teachers

\begin{abstract}
Abstrak Penelitian ini bertujuan untuk mengetahui pengaruh pemahaman agama terhadap kinerja guru Madrasah Ibtidaiah di Kota Manado. Metode yang digunakan dalam penelitian ini adalah metode kuantitatif korelasional. Penelitian ini dilaksanakan di Madrasah Ibtidaiah di Kota Manado dengan sampel 96 yang diambil dari 127 guru dengan menggunakan proportional stratified random sampling. Pengumpulan data dilakukan dengan menggunakan instrumen tes dan nontes. Tes digunakan untuk mengumpulkan data tentang pemahaman agama dan nontes digunakan untuk mengumpulkan data pengamalan dan kinerja. Data yang terkumpul kemudian dianalisis dengan menggunakan analisis deskriptif dan analisis jalur. Hasil penelitian ini menunjukkan bahwa pemahaman agama berpengaruh langsung positif terhadap kinerja guru. Untuk meningkatkan kinerja guru, maka upaya yang dilakukan terkait dengan variabel tersebut di antaranya meningkatkan pemahaman agama guru dengan memperbaharui pengetahuan agama guru dengan memperkuat keimanan dan ketaqwaan kepada Tuhan, dan meningkatkan kesadaran diri, bahwa ketaatan dan kesungguhan dalam mengaplikasikannya adalah keniscayaan.
\end{abstract}

Kata Kunci: Pemahaman agama, kinerja, guru. 


\section{Pendahuluan}

Sumber daya manusia merupakan salah satu faktor penting dalam rangka menentukan keberhasilan suatu organisasi. Oleh karena itu, dalam melakukan pengelolaan sumber daya manusia perlu menggunakan pendekatan yang bersifat multidimensional dan dapat mencakup berbagai aspek seperti politik, ekonomi, sosial, budaya, keamanan serta teknologi dan administrasi. Pada sisi lain masih banyak tantangan yang dihadapi dalam upaya menciptakan organisasi yang efektif dan efisien. Daft, menyatakan bahwa "Management is the attainment of organizational goals in an effective and efficient manner through planning, organizing, leading and controlling organizational resources" (Daft, 1988, p. 5). Manajemen adalah tindakan mencapai tujuan organisasi secara efektif dan efisien melalui perencanaan, pengorganisasian, pengarahan dan pengontrolan sumber daya organisasi.

Pada era globalisasi tuntutan akan kemampuan dan kompetensi diri sudah merupakan hal yang wajar dan harus dilakukan sebagai suatu upaya dini dalam menjawab tantangan, termasuk menguasai ilmu pengetahuan, teknologi dan informasi sesuai dengan keadaan dan perkembangan zaman.

Lembaga pendidikan Islam dalam hal ini madrasah sebagai salah satu institusi pendidikan tentu memiliki keterkaitan dengan berbagai hal, baik dari segi manajemen, sumber daya manusia, kinerja, kepemimpinan maupun permasalahan lainnya. Dalam rangka peningkatan pelayanan kepada para penggunanya maka lembaga pendidikan Islam dituntut untuk bisa menjalankan fungsi dan tugasnya.

Lembaga pendidikan Islam sebagai organisasi nirlaba terus mengalami perkembangan dan perubahan-perubahan karena berbagai tantangan yang harus dihadapi, baik yang berasal dari dalam organisasi sendiri maupun yang berasal dari luar organisasi.

Untuk menghadapi berbagai tantangan dan perubahan tersebut diperlukan adanya pengelolaan terutama sumber daya manusia agar organisasi tetap eksis dan mampu menyesuaikan diri dengan perkembangan zaman. Untuk mengelola sumber daya manusia secara efektif diperlukan seni mengelola yang baik. Dengan demikian aspek manajerial memegang peranan penting. Organisasi yang didukung oleh sumber daya manusia yang mampu dan mumpuni serta mau bekerja keras sesuai dengan bidang tugasnya masing-masing, loyal pada tempat di mana ia bekerja akan dapat meningkatkan keberhasilan suatu organisasi.

Guru merupakan SDM yang berpotensi dan dapat berfungsi sebagai modal (non material/finansial) dalam suatu organisasi, serta dapat berfungsi nyata baik secara fisik maupun non fisik untuk mewujudkan eksistensi organisasi yang akan berpengaruh terhadap efektivitas suatu pekerjaan.

Dengan demikian pengelola lembaga pendidikan Islam baik itu tenaga administratif maupun tenaga pengajar (guru) merupakan faktor utama dalam penyelenggaraan fungsinya sebagai lembaga pendidikan. Sarana/prasarana, pendanaan, perangkat peraturan akan menjadi tidak produktif tanpa didukung guru yang cakap dan berdedikasi tinggi. Guru yang memiliki kinerja yang baik akan membantu organisasinya untuk mencapai tujuan secara maksimal.

Kinerja merupakan prestasi kerja seseorang dalam melaksanakan tugasnya sesuai dengan tanggung jawab yang diembannya. Ada banyak aspek yang dapat memengaruhi kinerja seorang guru. Di antaranya adalah yang berkaitan dengan aspek-aspek manajemen seperti budaya kerja, lingkungan dan etos kerja, di samping juga terdapat faktor lain yang relatif jarang dipotret yakni berhubungan dengan aspek spiritualitas seperti pemahaman agama. 
Pemahaman agama adalah bagaimana seseorang memahami ajaran agamanya. Dalam agama Islam, setiap pemeluknya diajarkan untuk senantiasa memiliki totalitas ketika mengerjakan sesuatu. Ketika guru di lembaga pendidikan Islam yang notabene beragama Islam memiliki pemahaman yang baik dengan agamanya, maka seharusnya akan berpengaruh terhadap kinerjanya. Hal ini tidak bisa terlepas dari konsep Islam tentang Bekerja itu sendiri. Alquran sebagai sumber utama dalam agama Islam, terdapat banyak penjelasan Allah Swt., yang berkaitan dengan kerja, seperti yang disebukan dalam dalam Qs. Alqashsash (28):77, Atthin (95):6, Albayyinah (98):7, dan Alzalzala (99):7-8. Dengan demikian, maka Alquran sebagai pedoman hidup dalam ber-Islam pada gilirannya akan menjadi pedoman kerja bagi umat Islam itu sendiri.

Berdasarkan pengamatan langsung peneliti, salah satu yang dihadapi oleh sejumlah guru di lingkungan lembaga pendidikan Islam di Kota Manado adalah rendahnya kinerja guru. Hal ini lebih disebabkan oleh beberapa faktor yaitu, budaya dan lingkungan kerja yang belum mendukung terciptanya kinerja yang baik, kemampuan memahami sumber ajaran agama relatif rendah, yang kemudian menjadikan pengamalannya kurang berkualitas dan masih berorientasi pada aspek eksoteris agama serta perhatian guru pada tugas pokok dan fungsinya masih rendah. Hal itu bisa terlihat antara lain dari gejala seperti efektivitas guru yang menurun, rendahnya kesadaran dalam menunaikan kewajiban sehingga membuat sulitnya mewujudkan tujuan-tujuan organisasi.

Berdasarkan uraian-uraian di atas, maka peneliti menjadi tertarik untuk menguji apakah faktor pemahaman agama memiliki pengaruh terhadap kinerja guru pada Madrasah Ibtidaiah Kota Manado.

\section{Metodologi}

Penelitian ini bertujuan untuk mengetahui gambaran dan pengaruh antara pemahaman agama terhadap kinerja guru. Penelitian ini merupakan penelitian kuantitatif dengan menggunakan metode penelitian survei, yakni untuk memperoleh dan menggunakan data yang bersifat kuantitatif. Instrumen yang digunakan dalam penelitian ini adalah soal tes untuk mengukur pemahaman agama guru. Instrumen penelitian yang dibuat sebelum digunakan dalam penelitian terlebih dahulu diuji coba untuk mengetahui validitas dan reliabilitas. Hasil uji coba instrumen dikatakan valid dan reliabel ( $\left.\mathrm{r}_{\text {hitung }}>\mathrm{r}_{\text {tabel }}\right)$.

Penelitian ini dilaksanakan di Madrasah Ibtidaiah di Kota Manado. Subjek penelitian ini adalah guru Madrasah Ibtidaiah (MI) Kota Manado. Populasi dalam penelitian ini adalah seluruh guru Madrasah Ibtidaiah di Kota Manado sebanyak 127 guru. Penentuan sampel dilakukan dengan cara simple random sampling dengan jumlah sampel sebanyak 96 orang.

Data yang diperoleh dalam penelitian ini diolah dan dianalisis dengan teknik statistik deskriptif dan statistik inferensial. Analisis data secara deskriptif, dilakukan untuk menganalisis data yang telah terkumpul guna memperoleh gambaran karakteristik penyebaran nilai variabel yang diteliti. Analisis deskriptif digunakan dalam hal penyajian data yang dilakukan dengan langkah-langkah: perhitungan skor rata-rata (mean), modus, standard deviasi, varians, skor maksimum dan minimum. Analisis data secara inferensial dilakukan untuk menguji hipotesis dengan menggunakan analisis jalur (path analysis). Namun sebelum dilakukan pengujian hipotesis terlebih dahulu diadakan uji persyaratan analisis yakni uji normalitas, linearitas dan uji model. Setelah data dikatakan memenuhi syarat normalitas dan linearitas kemudian dilanjutkan dengan uji hipotesis. 


\section{Deskripsi Konseptual}

\subsection{Kinerja Guru}

Terminologi kinerja, dalam pandangan berbagai pakar manajemen mempunyai beragam pengertian. Akan tetapi, secara substansial pengertian-pengertian yang dikemukakan itu mempunyai persamaan. Husaini Usman, menyatakan bahwa kinerja itu adalah hasil interaksi antara motivasi dan kemampuan yang dikenal dengan teori harapan (expectancy theory) (Usman, 2004). Dengan demikian orang yang tinggi motivasinya tetapi memiliki kemampuan yang rendah akan menghasilkan kinerja yang rendah.

Selanjutnya, Simamora mengemukakan kinerja (employee performance) adalah tingkatan di mana seseorang mampu mencapai persyaratan-persyaratan pekerjaan (Simamora, 2001). Penilaian kinerja (performance appraisal) adalah proses yang mengukur kinerja guru. Berk menyatakan, kinerja adalah, "Performance on a job function is the record of outcomes achieved in carrying out the job function during a specified period" (Berk, 1986). Kinerja adalah catatan dari hasil yang dicapai dalam menyelesaikan pekerjaan selama periode waktu tertentu.

Dari batasan-batasan pengertian di atas, jelaslah bahwa yang dimaksud dengan kinerja adalah keberhasilan seseorang dalam melaksanakan pekerjaannya menurut ukuran yang berlaku untuk pekerjaan yang bersangkutan.

Dale menyatakan bahwa faktor-faktor yang memengaruhi kinerja dapat dikelompokkan menjadi dua, yaitu yang bersifat internal atau disposisional (dihubungkan dengan sifat-sifat orang) dan yang bersifat eksternal atau situasional (yang dapat dihubungkan dengan lingkungan seseorang) (Dale, 2001).

Untuk mengukur atau menilai kinerja guru, masalah yang paling pokok adalah menetapkan kriterianya. Menurut Simamora, karakteristik kriteria kinerja yang baik antara lain adalah: (a) harus mampu diukur, (b) mampu membedakan individu-individu sesuai dengan kinerja mereka, (c) sensitif terhadap masukan dan tindakan-tindakan dari pemegang jabatan dan, (d) harus dapat diterima oleh individu yang mengetahui kinerjanya sedang dinilai (Simamora, 2001).

Sejalan dengan uraian di atas, Siagian menyatakan bahwa penilaian kinerja merupakan bagian penting dari seluruh proses kekaryaan yang bersangkutan (Siagian, 2001). Pentingnya penilaian kinerja yang rasional dan ditetapkan secara obyektif terlihat pada paling sedikit dua kepentingan, yaitu kepentingan guru yang bersangkutan sendiri dan kepentingan organisasi.

Guru merupakan unsur penting yang terdapat dalam sesuatu lembaga pendidikan karena merupakan sumber daya yang potensial untuk dikelola serta dikembangkan kemampuan dan kemauannya untuk mendapatkan hasil yang optimal dari sebuah lembaga pendidikan. Oleh karena itu, perlu upaya untuk mengembangkan kemampuannya dengan melakukan sesuatu pembinaan sehingga dapat digunakan untuk memperbaiki dan meningkatkan kinerjanya. Perbaikan dan pembinaan kinerja guru hendaknya dilakukan secara bertahap dan berkelanjutan. Adapun guru yang dimaksud dalam penelitian ini adalah guru-guru Madrasah Ibtidaiah Negeri maupun Swasta di Kota Manado. Guru-guru dimaksud adalah mereka yang sudah berstatus sebagai Guru Pegawai Negeri Sipil maupun Guru NonPegawai Negeri Sipil.

\subsection{Pemahaman Agama}

Kehadiran agama tidak lepas dari keyakinan adanya sesuatu yang memiliki kekuasaan terhadap alam semesta ini (Siagian, 2001). Sesuatu yang memiliki kekuasaan itu biasa dikenal dengan "kuasa yang transenden", "sesuatu di luar", "realitas supranatural" ataupun definisi-definisi yang lain (Jalaluddin, 2005). Bahkan perasaan 
tentang yang ghaib (numinous) mendahului setiap hasrat untuk menjelaskan asal-usul dunia atau menemukan landasan bagi perilaku beretika (Armstrong, 2007).

Agama yang pada hakikatnya adalah keyakinan akan adanya Tuhan yang tidak bisa dipisahkan dari kehidupan manusia, maka sangat perlu dipahami secara seksama oleh setiap manusia. Meskipun demikian, terdapat kesulitan untuk bisa mendefinisikan agama dengan cermat. Hal ini dikarenakan pendefinisian agama berpotensi mengandung muatan subjektivitas dari orang yang mengartikannya (Abudin, 2004).

Menurut Mukti Ali terdapat tiga alasan kesulitan memberikan definisi terhadap kata agama yaitu. Pertama, menyangkut pengalaman agama yang sangat batiniah serta individualis. Kedua, pembicaraan agama identik dengan emosional pembicaranya serta ketiga konsepsi tentang agama biasanya mendapat pengaruh dari orang yang memberikan definisi (Alim, 1971).Sedangkan Sastrapredja menyatakan bahwa salah satu kesulitan ketika harus berbicara tentang agama adalah perbedaan dalam memahami arti agama. Selain itu juga terdapat perbedaan dalam penerimaan setiap agama terhadap sesuatu usaha dalam memahami agama (Sastrapredja, 1991).

Meskipun demikian, setidaknya beberapa ahli dengan latar belakang masingmasing tetap berupaya memberikan pengertian agama baik secara kebahasaan (etimologis) maupun istilah (terminologi). Beberapa definisi tersebut dikemukakan di bawah ini.

Secara bahasa, perkataan "agama" berasal dari bahasa Sangsekerta yang erat hubungannya dengan agama Hindu dan Budha yang berarti "tidak pergi atau tetap di tempat, diwarisi turun-temurun" (Harun, 2001). Selain itu ada juga yang berpendapat bahwa kata agama berasal dari bahasa Sangsekerta, yang berasal dari akar kata gam artinya pergi. Kemudian akar kata gam tersebut mendapat awalan a dan akhiran a, maka terbentuklah kata agama artinya jalan. Maksudnya, jalan untuk mencapai kebahagiaan. Di samping itu, ada pendapat yang menyatakan bahwa kata agama berasal dari bahasa Sangsekerta yang akar katanya adalah a dan gama. A artinya tidak dan gama artinya kacau. Jadi, agama artinya tidak kacau atau teratur.

Dalam Islam, padanan kata agama adalah ad din. kata din-secara etimologi-berasal dari bahasa Arab, artinya: patuh dan taat, undang-undang, peraturan dan hari kemudian (Harun, 2001). Din juga membawa peraturan-peraturan berupa hukum-hukum yang harus dipatuhi baik dalam bentuk perintah yang wajib dilaksanakan maupun berupa larangan yang harus ditinggalkan.

Kata din dalam Al Quran disebut sebanyak 94 kali dalam berbagai makna dan konteks, antara lain berarti Pembalasan (QS. Al Fatihah (1) ayat 4. Undang-undang duniawi atau peraturan yang dibuat oleh raja (QS.. Yusuf (12)ayat 76. Agama yang datang dari Allah Swt.,, bila dirangkaikan dengan kata Allah (QS.. Ali Imran (3) ayat 83. Agama yang dibawa oleh Rasulullah Muhammad Saw., sebagai agama yang benar, yakni Islam, bila kata din dirangkaikan dengan kata al-Haq (QS.. At Taubah (9) ayat 33. Agama selain Islam (Qs. Al Kafirun (109) ayat 6 dan Qs. Ash Shaf (61) ayat 9 .

Secara istilah, agama adalah gejala umum yang terjadi di banyak tempat yang berkaitan dengan usaha manusia untuk mengukur dalamnya makna dari keberadaannya sendiri serta alam semesta (Elizabeth, 1985). Sosiolog yang lain Durkheim menyatakan bahwa agama merupakan pantulan dari solidaritas sosial. Lebih lanjut dalam pandangannya juga disebutkan bahwa Tuhan adalah ciptaan masyarakat (Taufik, 1990).

Kedua pendapat di atas didasarkan atas pengamatan bentuk luar dari agama. Aspek lahiriah atau apa yang dipraktikkan dalam kenyataan dari agamalah yang menjadi patokan mereka dalam mendefinisikannya. Hal ini sangat wajar mengingat latar be- 
lakang keilmuan mereka serta bagaimana kesulitan yang dihadapi oleh para ahli untuk mendefinisikan agama itu sendiri.

Selanjutnya, menurut Thaib Thahir Abdul Mu'in agama adalah peraturan Tuhan yang mendorong jiwa seseorang dengan kehendak dan pilihannya sendiri mengikuti peraturan tersebut guna mencapai kebahagiaan hidupnya di dunia dan akhirat (Taib, 1986).

Dari berbagai pendapat di atas, dapat disimpulkan bahwa agama adalah undangundang atau peraturan-peraturan yang mengikat manusia dalam hubungannya dengan Tuhannya, hubungan manusia dengan sesama manusia dan hubungan manusia dengan alam. Maka orang yang beragama adalah orang yang teratur, orang yang tenteram dan orang yang damai baik dengan dirinya maupun dengan orang lain dari segala aspek kehidupannya.

Agama merupakan hal yang tidak bisa dipisahkan dalam kehidupan masyarakat dewasa ini. Di Indonesia, keberadaan agama menjadi penting dalam kaitannya dengan kehidupan bernegara. Hal ini berbeda dengan masyarakat barat yang tidak mempermasalahkan orang yang tidak beragama (atheis). Karena itulah maka studi-studi tentang agama kemudian menjadi marak di Indonesia (Amin, 2000).

Pemahaman terhadap agama, bisa disebut juga dengan iman. Dalam ajaran Islam, iman dari seorang pemeluknya menuntut aplikasi dalam kehidupan sehari-harinya. Baik dalam bentuk perkataan ataupun perbuatan, ketika berinteraksi dengan Tuhannya ataupun dengan makhluk ciptaan-Nya yang lain. Bagaimana seorang yang beragama memahami konsep agamanya dapat diindikasikan dari interaksi pemeluknya terhadap perilaku sosialnya.

Mengacu pada uraian tentang pemahaman agama di atas, maka agama praktis menjadi kontrol dari perjalanan hidup pemeluknya, bahkan pada tingkatan yang lebih jauh terhadap setiap perubahan sosial yang ada dalam kehidupan masyarakat. Nilai-nilai agama tersebut secara simultan memberi kontribusi aktif terhadap perilaku masyarakat.

Penjelasan-penjelasan di atas, menuntut pemahaman agama harus selalu berpacu dengan perubahan sosial, dan bukan menjadi penghambat bagi perubahan. Dengan kata lain, agama harus menjadi motor perubahan (spirit of change) yang mendahului segala perubahan dan bukan sebaliknya, yakni agama menjadi justifikasi dan legitimasi dari perubahan itu sendiri.Pemahaman terhadap sebuah agama memiliki implikasi yang sangat luas terhadap kehidupan masyarakat penganutnya. Dalam Islam, pemahaman terhadap ajaran agama merupakan hal yang sangat penting. Hal ini karena selain dipahami, agama juga menuntut untuk diamalkan. Bahkan, agama harus termanifestasikan dalam bentuk amal perbuatan sehari-hari dan dari waktu ke waktu (Afif, 1998).

Berdasarkan konsep pemahaman agama sebagaimana telah diuraikan di atas, pemahaman dimaksud dalam penelitian ini adalah pengetahuan seseorang dalam memahami aspek-aspek agamanya (agama Islam). Karena itu pemahaman agama adalah pengetahuan seorang guru menyangkut aspek ritual dan non ritual agama Islam. Indikator pemahaman agama adalah pemahaman tentang aspek-aspek ibadah mahdah seperti tayammum, salat, zakat dan haji serta aspek ibadah ghairumahdah berupa hak dan kewajiban seorang muslim terhadap makhluk Allah yang lain. Juga tentang munakahat, muamalah serta mawaris.

\section{Kerangka Teoretik}

Agama merupakan hal yang tidak bisa dipisahkan dalam setiap kehidupan masyarakat di Indonesia. Hal ini karena beragama merupakan kewajiban setiap warga 
negara. Tanpa memeluk sebuah agama, maka belum lengkaplah status seseorang sebagai warga negara Republik Indonesia. Konsekuensi sebagai pemeluk agama, seorang haruslah memahami agama yang diyakininya.

Dengan status sebagai lembaga pendidikan Islam, maka keberadaan para gurunya adalah seratus persen memeluk agama Islam. Pemahaman agama dalam Islam bisa disebut dengan Iman. Islam memiliki rukun yang berkaitan dengan iman dan dikenal dengan rukun iman. Rukun iman sendiri merupakan hal-hal yang harus diimani oleh setiap pemeluknya yaitu percaya kepada Allah, Malaikat, Kitab, Nabi dan Rasul, Hari Kiamat serta Takdir baik dan buruk.

Pemahaman agama adalah pengetahuan seorang guru menyangkut aspek ritual dan nonritual agama Islam. Paham tidaknya seseorang tentang agama dapat dilihat dari pengetahuannya tentang aspek-aspek ibadah mahdah seperti tayammum, salat, zakat dan haji serta aspek ibadah ghairumahdah berupa hak dan kewajiban seorang muslim terhadap makhluk Allah yang lain. Juga tentang munakahat, muamalah serta mawaris. Dengan memiliki kepercayaan terhadap hal-hal dimaksud, maka seorang muslim dalam perilakunya harus senantiasa dibarengi dengan keyakinan bahwa segala perbuatan yang dilakukan di dunia akan mendapatkan balasan kelak di akhirat. Pernyataan ini sejalan dengan teori perilaku yang menyatakan bahwa, norma-norma agama merupakan motivator dan dinamisator pemunculan perilaku disiplin dalam realitas kehidupan dan nilai ilahiah sebagai supremasi refrensif (Iffattin, 2007). Oleh karenanya dapat disimpulkan bahwa jika pemahaman agama baik, maka kinerjanya juga akan baik. Sehingga pemahaman agama diduga berpengaruh langsung positif terhadap kinerja guru.

\section{Hasil Penelitian dan Pembahasan}

\subsection{Deskripsi Data}

Data hasil penelitian terhadap variabel kinerja guru (Y), pemahaman agama (X1), yang dianalisis melalui statistik deskriptif yang disajikan dalam tabel sebagai berikut:

Tabel 1. Rangkuman Hasil Analisis Statistik Deskriptif

\begin{tabular}{|l|c|c|}
\hline \multirow{2}{*}{\multicolumn{1}{c|}{ Analisis }} & \multicolumn{2}{c|}{ Data Variabel } \\
\cline { 2 - 3 } & $\mathrm{Y}$ & $\mathrm{X} 1$ \\
\hline Banyaknya data (n) & 96 & 96 \\
\hline Minimum & 122 & 17 \\
\hline Maximum & 40 & 31 \\
\hline Range & 18 & 14 \\
\hline Interval & 2 & 2 \\
\hline Banyak kelas & 8 & 8 \\
\hline Mean & 129,61 & 25,23 \\
\hline Std. Deviation & 3,64 & 2,94 \\
\hline Variance & 13,27 & 8,66 \\
\hline Median & 129 & 25 \\
\hline Mode & 129 & 25 \\
\hline
\end{tabular}

Keterangan:

$$
\begin{array}{cl}
\text { Y } & \text { Kinerja Guru MI di Kota Manado } \\
\text { X1 } & \text { Pemahaman Agama }
\end{array}
$$

Deskripsi data yang disajikan adalah deskripsi data variabel-variabel penelitian yang terdiri dari dua variabel bebas yaitu pemahaman agama dan pengamalan ibadah, 
serta satu variabel terikat yaitu kinerja guru. Penyajian deskripsi data disajikan masing-masing variabel secara berturut-turut yaitu sebagai berikut:

\subsubsection{Kinerja Guru}

Data penelitian kinerja guru (Y) yang diperoleh dengan menggunakan angket menunjukkan rentang skor 18 . Hasil perhitungan menunjukkan rata-rata 129.61; standar deviasi 3,64; mode 129, dan varian 13,27. Data nilai skor variabel ini menggunakan aturan Strugess yang disajikan dalam bentuk distribusi frekuensi kelompok yang terdiri atas 8 kelas dengan panjang kelas interval 2, yang dapat dilihat pada tabel 2 dan histogram pada gambar 1 sebagai berikut:

Tabel 2. Distribusi Frekuensi Skor Kinerja Guru

\begin{tabular}{|c|c|c|c|c|c|}
\hline \multirow{2}{*}{ No } & Kelas & \multicolumn{4}{|c|}{ Frekuensi } \\
\cline { 2 - 6 } & Interval & Absolut & Relatif \% & Kumulatif & Kumulatif \% \\
\hline 1 & $122-123$ & 4 & 4,17 & 4 & 4,17 \\
\hline 2 & $124-125$ & 8 & 8,33 & 12 & 12,50 \\
\hline 3 & $126-127$ & 7 & 7,29 & 19 & $19 ., 79$ \\
\hline 4 & $128-129$ & 48 & 50 & 67 & 69,79 \\
\hline 5 & $130-131$ & 4 & 4,17 & 71 & 73,96 \\
\hline 6 & $132-133$ & 2 & 2,08 & 73 & 76,04 \\
\hline 7 & $134-135$ & 16 & 16,67 & 89 & 92,71 \\
\hline 8 & $136-140$ & 7 & 7,29 & 96 & 100 \\
\hline \multicolumn{7}{|c}{ Jumlah } & 96 & 100 & & \\
\hline
\end{tabular}

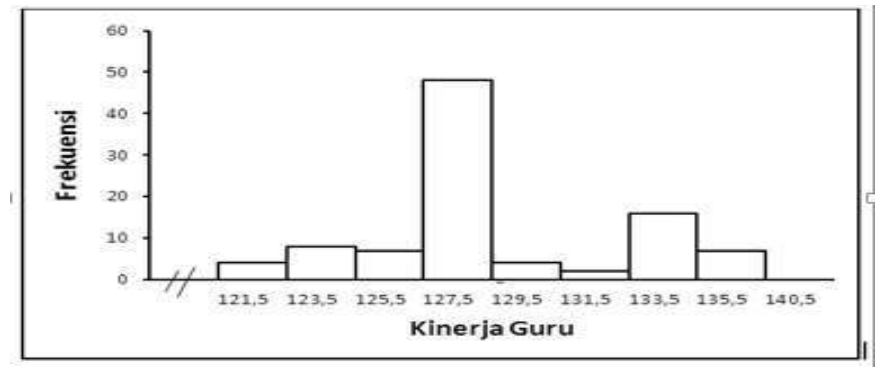

Gambar 1. Histogram Data Variabel Kinerja Guru

\subsubsection{Pemahaman Agama}

Data penelitian untuk pemahaman agama dengan diperoleh melalui tes menunjukkan rentang skor empirik antara 17-31, dengan rentangan skor teoritik 031. Hasil perhitungan menunjukkan rata-rata 25,23; simpangan baku 2,94; mode 25, dan varian 8,66. Data nilai skor variabel ini menggunakan aturan Strugess yang disajikan dalam bentuk distribusi frekuensi kelompok yang terdiri atas 8 kelas interval dengan panjang kelas interval 2, yang dapat dilihat pada tabel 3 dan histogram pada gambar 2 sebagai berikut:

Tabel 3. Distribusi Frekuensi Pemahaman Agama

\begin{tabular}{|c|c|c|c|c|c|}
\hline \multirow{2}{*}{ No } & Kelas & \multicolumn{4}{|c|}{ Frekuensi } \\
\cline { 2 - 6 } & Interval & Absolut & Relatif \% & Kumulatif & Kumulatif \% \\
\hline 1 & $17-18$ & 2 & 2,08 & 2 & 2,08 \\
\hline 2 & $19-20$ & 5 & 5,21 & 7 & 7,29 \\
\hline 3 & $21-22$ & 6 & 6,25 & 13 & 13,54 \\
\hline 4 & $23-24$ & 24 & 25 & 37 & 38,54 \\
\hline 5 & $25-26$ & 28 & 29,17 & 65 & 67,71 \\
\hline 6 & $27-28$ & 16 & 16,67 & 81 & 84,38 \\
\hline 7 & $29-30$ & 11 & 11,46 & 92 & 95,83 \\
\hline 8 & $31-32$ & 4 & 4,17 & 96 & 100 \\
\hline \multicolumn{7}{|c}{ Jumlah } & 96 & 100 & & \\
\hline
\end{tabular}




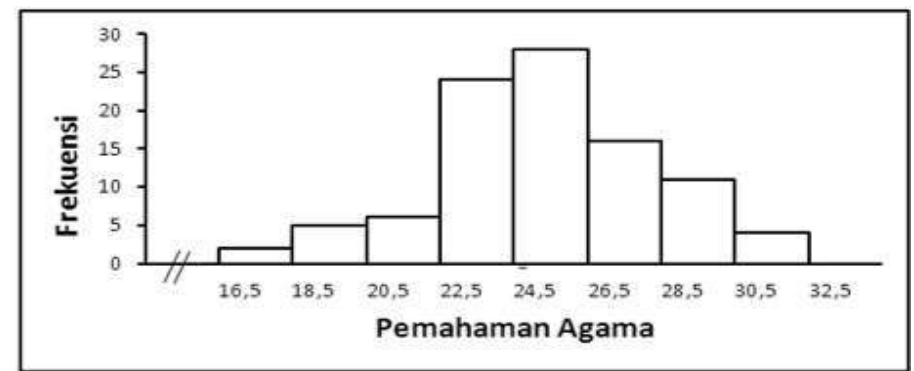

Gambar 2. Histogram Data Variabel Pemahaman Agama

\subsection{Pengujian Persyaratan Analisis}

Uji normalitas dan uji linearitas data dilaksanakan untuk menguji persyaratan analisis terhadap data penelitian. Hasil pengujiannya disajikan sebagai berikut:

\subsubsection{Uji Normalitas}

Pengujian normalitas dalam penelitian ini menggunakan uji Liliefors. Dengan menggunakan uji Liliefors, maka data dapat dinyatakan normal jika $\mathrm{L}_{\text {hitung }}<$ $\mathrm{L}_{\text {tabel. }}$ Rangkuman hasil perhitungan uji normalitas untuk masing-masing galat taksiran adalah sebagai berikut:

Uji normalitas galat taksiran $\mathrm{Y}$ atas $\mathrm{X}_{1}$ dengan uji Liliefors diperoleh $\mathrm{L}_{\text {hitung }}=$ 0.087 , sedangkan nilai kritis $\mathrm{L}_{\text {tabel }}$ untuk $\mathrm{n}=96$ pada $\alpha=0.05$ adalah 0.100 . Dari hasil perhitungan yang diperoleh diketahui $\mathrm{L}_{\text {hitung }}<\mathrm{L}_{\text {tabel, }}$, sehingga dapat disimpulkan bahwa galat taksiran $\mathrm{Y}$ atas $\mathrm{X}_{1}$ berdistribusi normal.

\subsubsection{Uji Signifikansi dan Linearitas}

Hasil pengujian signifikansi regresi Kinerja guru atas pemahaman agama diperoleh $F_{\text {hitung }}$ sebesar 145,353 sedangkan nilai $F_{\text {tabel }}$ pada $\alpha=0.05$ adalah 3.95. Hasil analisis terlihat nilai $\mathrm{F}_{\text {hitung }}>\mathrm{F}_{\text {tabel, }}$, sehingga dapat disimpulkan bahwa persamaan regresi Kinerja guru atas pemahaman agama adalah sangat signifikan. Sedangkan untuk uji linearitas regresi Kinerja guru atas pemahaman agama diperoleh $F_{\text {hitung }}$ sebesar 1.418, sedangkan nilai $F_{\text {tabel }}$ pada $\alpha=0.05$ dengan dk pembilang 13 dan dk penyebut 81 sebesar 2,37. Dari hasil uji tersebut terlihat nilai $F_{\text {hitung }}<F_{\text {tabel, }}$ sehingga dapat disimpulkan bahwa persamaan regresi variabel Kinerja guru atas pemahaman agama berbentuk linear.

\subsection{Pengujian Hipotesis}

Setelah analisis model struktural dilakukan, hasil yang diperoleh digunakan untuk menguji hipotesis yang diajukan dan mengukur besarnya pengaruh langsung antar variabel. Kesimpulan terhadap hipotesis yang diajukan akan ditarik melalui koefisien jalur dan uji keberartian untuk setiap jalur yang diteliti.Hipotesis ini secara statistik dapat dirumuskan sebagai berikut:

$$
\begin{aligned}
& \mathrm{H}_{0}: \beta_{\mathrm{y} 1} \leq 0 \\
& \mathrm{H}_{1}: \beta_{\mathrm{y} 1}>0
\end{aligned}
$$

Berdasarkan hasil perhitungan uji t pemahaman agama terhadap kinerja guru $=0,274$ dengan, $t_{\text {hitung }} 3,274$. Karena $t_{\text {hitung }}=3,274>t_{\text {tabel }}=1,98$. Maka $H_{0}$ ditolak yang berarti terdapat pengaruh langsung positif pemahaman agama terhadap kinerja guru Madrasah Ibtidaiah di Kota Manado. Dengan demikian dapat dinyatakan, hasil analisis dan pengujian hipotesis menunjukkan bahwa hipotesis nol yang diajukan dalam penelitian ini ditolak sehingga dapat disimpulkan bahwa terdapat pengaruh pemahaman agama terhadap kinerja guru Madrasah Ibtidaiah di Kota Manado. 